\title{
THE EFFECT OF SMOKING ON NUTRITIONAL STATUS, SEVERITY OF THE DISEASE AND THE DEVELOPMENT OF SYSTEMIC EFFECTS IN PATIENTS WITH CHRONIC OBSTRUCTIVE PULMONARY DISEASE
}

10.36740/WLek202101110

\author{
Olha 0. Boiko, Viktoriia V. Rodionova \\ DNIPROPETROVSK MEDICAL ACADEMY OF THE MINISTRY OF HEALTH OF UKRAINE, DNIPRO, UKRAINE
}

\begin{abstract}
The aim: To determine the effect of smoking on indicators of nutritional status in patients with chronic obstructive pulmonary disease (COPD).

Materials and methods: A study included 91 patients with COPD. Patients were divided into two groups depending on the status of smoking: smokers and non-smokers. Everyone underwent an assessment of the severity of COPD, a study of nutritional status, a laboratory study of kidney function and blood lipid profile.

Results: It was found that in smokers with COPD, the disease proceeds with more pronounced shortness of breath. There is also a development of sarcopenic obesity in those patients who smoke. In turn, it was found that bronchial obstruction increases with a decrease in muscle tissue content. Renal filtration function is reduced in smokers and non-smokers. Conclusions: 1. Patients suffering from COPD have a violation of nutritional status. Smoking patients develop sarcopenic obesity, which progresses with an increase in the degree of nicotine addiction, correlates with the "pack / year" index and is a predictor of increased mortality in this category of patients. 2. Increased bronchial obstruction in smokers with COPD is observed with an increase in smoking history, the number of cigarettes smoked and with a decrease in body weight. 3. Reducing the pool of muscle tissue can be considered as an early predictor of more frequent exacerbations in smoking patients with COPD. 4. The systemic effects of COPD include impaired renal function, more pronounced in smokers with COPD.
\end{abstract}

KEY WORDS: COPD, nutritional status, smoking, renal function

Wiad Lek. 2021;74(1):52-56

\section{INTRODUCTION}

Chronic obstructive pulmonary disease (COPD) is an urgent problem of modern pulmonology [1,2,3]. A feature of the disease is not only local damage to the respiratory tract, but also the development of systemic manifestations $[4,5,3]$. The main etiological factors for the development of COPD include tobacco smoking, air pollution in the industrial region, dust in the workplace and other factors. Data from large-scale population-based studies in recent years have shown that patients with COPD who do not smoke have a minimum total death rate with standardization by age with a body mass index (BMI) of 22.5-24.9 and $20-25 \mathrm{~kg} / \mathrm{m} 2$ [6]. Patients with more severe bronchial obstruction and BMI $<25 \mathrm{~kg} / \mathrm{m} 2$ have a higher risk of death compared with patients with COPD who are overweight and even obese [7]. It can be assumed that with an increase in BMI in patients with COPD, a more favorable outcome occurs. This phenomenon is also called the obesity paradox in COPD and it can be associated with the influence of adipose tissue on the respiratory mechanism (for example, the relative decrease in static pulmonary volumes in patients with COPD and obesity) $[8,9]$. A relationship was also established between a decrease in muscle tissue content in patients with COPD and an increase in the severity of the condition of these patients [10]. It is known that adipose tissue can be redistributed from subcutaneous fat to visceral, which is characterized by an increase in cardiovascular risk in patients with moderate COPD [11]. However, perhaps there are other mechanisms of the disease that are interrelated with the risk of mortality and the content of adipose tissue [12].

\section{THE AIM}

To determine the effect of smoking on indicators of nutritional status in patients with COPD, to identify the relationship between muscle and adipose tissue levels, nicotine dependence, smoking duration, "pack / year" index, severity of the disease, and the development of systemic effects in patients with COPD.

\section{MATERIALS AND METHODS}

A prospective study included 91 stable outpatients with COPD of clinical groups B and C according to the GOLD. The diagnosis of COPD was established according to the 
Table I. Clinical characteristics of control groups.

\begin{tabular}{cccc}
\hline Characteristics & $\begin{array}{c}\text { Group I } \\
\text { (non-smokers) }\end{array}$ & $\begin{array}{c}\text { Group II } \\
\text { (smokers) }\end{array}$ & p \\
\hline Age, y M (SD) & $55,8(6,7)$ & $58,3(8,1)$ & 0,1 \\
\hline Dyspnea severity mMRS, M (SD) & $2(1 ; 3)$ & $3(2 ; 4)$ & 0,047 \\
\hline Exacerbation rate (SD) & $1(1 ; 2)$ & $1(1,3)$ & 0,6 \\
\hline
\end{tabular}

Table II. Spirometry indices in the examined patients.

\begin{tabular}{cccc}
\hline Characteristics & $\begin{array}{c}\text { Group I } \\
\text { (non-smokers) }\end{array}$ & $\begin{array}{c}\text { Group II } \\
\text { (smokers) }\end{array}$ & p \\
\hline FVC, \% Me [25\%-75\%] & $85,0(77,0-92,0)$ & $87,5(70,0-96,0)$ & 0,8 \\
\hline FEV1, \% Me [25\%-75\%] & $51,0(44,0-62,0)$ & $45,0(34,0-59,0)$ & 0,04 \\
\hline FEV1\%M Me [25\%-75\%] & $54,5(37,0-65,0)$ & $48,0(54,0-62,0)$ & 0,3 \\
\hline MEF 75, \% Me [25\%-75\%] & $53,0(41,6-68,6)$ & $43,0(31,3-56,4)$ & 0,6 \\
\hline MEF 50, \% Me [25\%-75\%] & $19,5(25,5-51,5)$ & $40,0(18,7-55,2)$ & 0,2 \\
\hline MEF 25, \% Me [25\%-75\%] & $22,0(23,8-48,0)$ & $31,0(15,4-34,7)$ & 0,6 \\
\hline PEF, \% Me [25\%-75\%] & $54,5(37,0-65,0)$ & $50,5(30,7,0-65,0)$ & 0,5 \\
\hline IC_F, \% Me [25\%-75\%] & $57,5(47,2-69,6)$ & $52,5(17,7-65,0)$ & 0,8 \\
\hline
\end{tabular}

recommendations of GOLD 2018 (2). Patients were treated during 2018-2019 years.

Criteria for inclusion in the study: verified diagnosis of COPD in clinical groups $\mathrm{B}$ and $\mathrm{C}$, stable phase. The exclusion criteria from the study were: patients over 80 years old, history of acute cardiovascular events, clinically significant heart rhythm disturbances, previously diagnosed diabetes mellitus, kidney diseases, cancer, surgical operations during the last year.

The patients underwent a general clinical examination, including the assessment of complaints, medical history, determination of anthropometric indicators (height, weight, BMI, waist circumference), physical examination. The severity of COPD was determined on the basis of the frequency of exacerbations during the year, assessing dyspnea using the mMRS scale (The Modified Medical Research Counsil Dyspnea Scale), spirographic data (forced expiratory volume in 1 second (FEV1), and forced lung capacity (FVC), ratio - FEV1\% M). Additionally, the status of smoking and nicotine addiction (Fagerstrom Test for Nicotine Dependence - FTND) was evaluated. The percentages of total fat, muscle mass and visceral fat were determined on the basis of bioimpedancemetry data (Omron analyzer). Data were compared with reference values (13). The state of lipid metabolism was studied by the enzymatic method on a Humalayzer biochemical analyzer. The levels of total cholesterol $(\mathrm{H})$, low density lipoprotein cholesterol (LDL cholesterol), high density lipoprotein cholesterol (HDL cholesterol) and triglycerides (TG) were determined. We also performed a quantitative analysis of $\mathrm{C}$-reactive protein (CRP), investigated serum creatinine level, urine creatinine level, and glomerular filtration rate (GFR) was calculated using the CKD-EPI formula (Chronic Kidney Desease Epidemiology Collaboration), currently recommended for application as the most suitable in outpatient and clinical practice screening method for assessing glomerular filtration rate. The CKD-EPI method is considered universal and accurate at any stage of CKD [14]. All results obtained were compared with reference values.

The data obtained were processed using the program Statistica 10.0. with the determination of mean values $(\mathrm{M})$, standard deviation (SD) in the case of a normal distribution of values, and the median (Me), upper and lower quartiles $([25 \% ; 75 \%])$ in the case of a non-normal distribution. Parametric methods were used using Student's t-test in the case of a normal distribution of values. For a distribution other than normal, the nonparametric Mann-Whitney test was used. The probability of an error-free forecast of qualitative signs was carried out using the $\mathrm{Xi}$-square test (x2). When analyzing the data, the differences between the groups were considered significant at $\mathrm{p}<0.05$.

\section{RESULTS}

According to inclusion and exclusion criteria, 63 patients (52 men and 11 women) were included in the study, the average age of which was 57.3 (7.6) years. The average duration of COPD was 15 (3.6) years.

Depending on the smoking status, patients were divided into two groups: non-smoking patients - group I, smoking patients were included in group II (table I).

Group I included 26 patients (19 men and 7 women), whose average age was 55.8 (6.7) years. The severity of shortness of breath in accordance with the mMRS scale averaged $2(1 ; 3)$ points, the frequency of exacerbations in the previous year was $1(1 ; 2)$.

Group II consisted of 37 smoking patients (33 men and 4 women). The average age is 58.3 (8.1) years. The average severity score of dyspnea on the mMRS scale was $3(2 ; 4)$ points, the frequency of exacerbations over the past year 
Table III. Indicators of nutritional status in the examined patients with COPD.

\begin{tabular}{cccc}
\hline Characteristics & $\begin{array}{c}\text { Group I } \\
\text { (non-smokers) }\end{array}$ & $\begin{array}{c}\text { Group II } \\
\text { (smokers) }\end{array}$ & p \\
\hline Age, y M(SD) & $55,8(6,7)$ & $58,3(8,1)$ & 0,1 \\
\hline Body mass, kg Me [25\%-75\%] & $87,0(82,0-88,0)$ & $78,0(71,7-93,3)$ & 0,7 \\
\hline BMl, Me [25\%-75\%] & $26,3(25,0-30,0)$ & $26,6(23,9-30,3)$ & 0,9 \\
\hline Fat tissue, \% Me [25\%-75\%] & $25,05(24,6-25,1)$ & $35,1(31,1-37,5)$ & 0,001 \\
\hline Muscle tissue, \% Me [25\%-75\%] & $39,9(34,5-44,9)$ & $20,8(16,8-29,7)$ & 0,002 \\
\hline Visceral fat, \% Me [25\%-75\%] & $10,5(8,0-12,0)$ & $8,0(5,5-11,0)$ & 0,2 \\
\hline Waist circumference, sm M(SD) & $95,5(1,5)$ & $91,5(1,7)$ & 0,3 \\
\hline
\end{tabular}

Table IV. Laboratory characteristics of blood and urine of patients with COPD.

\begin{tabular}{|c|c|c|c|}
\hline Characteristics & $\begin{array}{c}\text { Group I } \\
\text { (non-smokers) }\end{array}$ & $\begin{array}{c}\text { Group II } \\
\text { (smokers) }\end{array}$ & $\mathbf{p}$ \\
\hline CRP , mg / I Me [25\%-75\%] & $5,8(2,6-11,6)$ & $6,0(2,4-10,8)$ & 0,3 \\
\hline $\mathrm{H}, \mathrm{mmol} / \mathrm{I} \mathrm{Me}[25 \%-75 \%]$ & $4,6(4,3-5,5)$ & $4,6(3,8-5,3)$ & 0,4 \\
\hline LDL cholesterol, mmol / I Me [25 \%-75 \%] & $2,9(2,3-3,6)$ & $2,5(2,0-3,1)$ & 0,045 \\
\hline VLDL, $\mathrm{mmol} / \mathrm{I} \mathrm{Me}[25 \%-75 \%]$ & $0,5(0,4-0,7)$ & $0,5(0,4-0,8)$ & 0,6 \\
\hline HDL cholesterol, mmol / I Me [25 \%-75 \%] & $1,1(1,0-1,3)$ & $1,2(1,0-1,4)$ & 0,3 \\
\hline TG, mmol / I Me [25 \%-75 \%] & $1,1(0,9-1,5)$ & $1,2(0,9-1,7)$ & 0,9 \\
\hline AC Me $[25 \%-75 \%]$ & $3,0(2,2-4,2)$ & $2,8(2,0-3,3)$ & 0,1 \\
\hline Blood creatinine level , $\mu \mathrm{mol} / \mathrm{I}$ Me [25 \%-75 \%] & $92,0(79,8-96,5)$ & $84,8(76,2-90,3)$ & 0,6 \\
\hline GFR, $\mathrm{ml} / \mathrm{min} \mathrm{Me}[25 \%-75 \%]$ & $76,0(72,5-82,1)$ & $79,0(74,2-83,0)$ & 0,6 \\
\hline Urine creatinine level, $\mu \mathrm{mol} / \mathrm{I}$ Me [25 \%-75 \%] & $1078,4(551,6)$ & $1047,6(495,7)$ & 0,02 \\
\hline
\end{tabular}

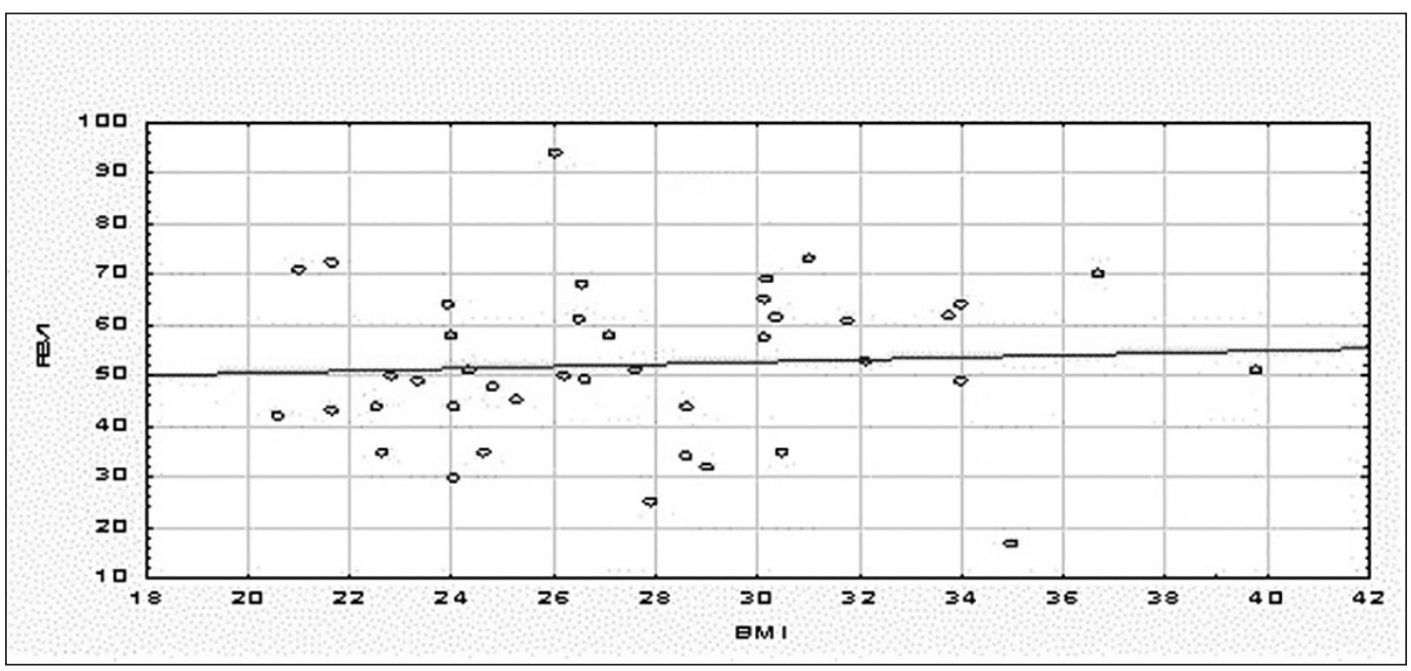

Fig. 1. The relationship between BMI and FEV1.

was 1 (1.3). The "pack / year" index was 29.8 (11.3). The degree of nicotine addiction according to the Fagerstrom test was 5.8 (1.8), which corresponded to the average level of dependence.

When comparing patients of both groups, there was no significant difference between the frequency of exacerbations by age, however, in smokers with COPD, the severity of shortness of breath was significantly higher (table I).

Significant differences confirming the high severity of bronchial obstruction in smokers with COPD were iden- tified on the basis of spirometry data: for group I patients, the FEV1 index was $51.0(44.0-62.0) \%$, in group II - 45.0 (34.0 -59.0)\% ( $\mathrm{p}=0.04)$ (table II).

Based on the conducted correlation analysis in patients of group II (smokers), an average negative correlation was found between the MOC 25 and the pack / year index $(\mathrm{R}=$ -0.5) $(\mathrm{p}<0.05)$.

Assessment of the nutritional status of patients was carried out on the basis of anthropometry and bioimpedancemetry data. BMI in patients of both groups did not 
practically differ, despite a decrease in average body weight in patients of group II (smokers). Significant differences were found between the content of fat and muscle mass: in patients in the group of smokers, the percentage of total fat was significantly higher than in non-smokers. At the same time, the percentage of muscle tissue in smokers was significantly lower (table III).

Correlation analysis data indicate the presence of a positive correlation of moderate degree between the FEV1 and BMI $(\mathrm{R}=0.4)$ in group II (smokers), between the indicator $(\mathrm{FEV} 1 \% \mathrm{M})$ and the percentage of visceral fat $(\mathrm{R}=-0.7)$ $(\mathrm{p}<0.05)$ revealed a strong negative correlation.

A moderate correlation was found between the number of exacerbations and the content of muscle tissue in smokers with $\operatorname{COPD}(\mathrm{R}=-0.5)(\mathrm{p}<0.05)$.

In the group of non-smokers, the level of LDL was 2.9 (2.3-3.6) $\mathrm{mmol} / \mathrm{L}$, in the group of smoking patients - 2.5 $(2.0-3.1) \mathrm{mmol} / \mathrm{L},(\mathrm{p}=0.045)$.

An average negative correlation between body weight and TG level $(\mathrm{R}=-0.68)(\mathrm{p}<0.05)$ was also obtained.

Thus, in the examined patients, urine creatinine level in group I was 1078.4 (551.6) $\mu \mathrm{mol} / \mathrm{L}$, in group II - 1047.6 $\mu \mathrm{mol} / \mathrm{L}(495.7)(\mathrm{p}=0.02)$.

Also, in all patients with COPD, a decrease in GFR below $90 \mathrm{ml} / \mathrm{min}$ was detected.

A strong negative correlation was found between urine creatinine level and the pack / year index $(R=-0.6)$ $(\mathrm{p}<0.05)$. A strong negative correlation between GFR and the degree of patients' compliance to smoking $(R=-0.7)$ was also determined.

\section{DISCUSSION}

In the course of the study, it was found that with an increase in the "pack / year" index in patients with COPD, the severity of bronchial obstruction increases, which confirms the literature [2]. Also, when studying the nutritional status, it was found that in patients with COPD who smoke, amid an increase in fat mass, a decrease in muscle mass was observed and sarcopenic obesity syndrome developed $[15,16]$. Our data confirm the literature data that in patients with smokers, against the background of a general decrease in body weight, primarily due to muscle mass, there is an increase in the content of visceral fat, which contributes to an increase in their degree of bronchial obstruction $[16,17]$. In smokers In patients, a decrease in muscle mass can contribute to an increase in the number of exacerbations of COPD, which is also reflected in the literature [6].

In patients with COPD there is a development of systemic effects and, above all, damage to the cardiovascular system, followed by the development of coronary artery disease, arterial hypertension, which, of course, is associated with changes in lipid metabolism, so the level of low density lipoproteins in patients of both groups exceeded the optimal level. It is of interest to identify a lower LDL content in smokers compared with non-smokers, which may be explained by the development in patients with COPD of systemic inflammation, more pronounced in smokers with
COPD. Thus, an increase in CRP was detected in patients of both groups with a predominance of the indicator in the group of smoking patients. It is known that the development of systemic inflammation reduces the pool of muscle tissue. Probably, in this situation, muscle cells that need protection need cholesterol, while they synthesize LDL receptors, which, after synthesis, are transported to the cell membrane. In the cell membrane, LDL receptors are found in clathrin-containing caveoles. The LDL circulating in the blood binds to these transmembrane receptors and is endocytosed by the cell. After absorption, LDL is delivered to endosomes, and then to lysosomes, where cholesterol esters are hydrolyzed and cholesterol enters the cell $[11,16]$.

Visceral obesity is prognostically unfavorable in terms of the development of renal pathology [18]. There is scientific evidence supporting a link between abdominal obesity, microalbuminuria (MAU) and renal failure. The metabolic pathway for the development of glomerulosclerosis involves the deposition of low-density lipoproteins and apoliproteins $\mathrm{B}$ and $\mathrm{E}$ in the structures of the kidney. The accumulation of lipids in the renal tissue, as with atherosclerosis, induces sclerosis, which contributes to the development of renal pathology. Also, in all patients with COPD, a decrease in renal filtration function was detected. The effect of smoking on the development of metabolic disorders in the kidneys is evidenced by the obtained strong negative correlation between urine creatinine level and pack / year index: with an increase in smoking history, the percentage of muscle mass decreases, and, in turn, the blood and urine creatinine level, as creatinine is directly proportional to the amount of muscle tissue. A strong negative correlation between GFR and the degree of patients' compliance to smoking was also determined. Thus, in patients with COPD with nicotine dependence, there is a deterioration in renal function $[12,19,20]$.

\section{CONCLUSIONS}

1. Patients suffering from COPD have a violation of nutritional status. Smoking patients develop sarcopenic obesity, which progresses with an increase in the degree of nicotine addiction, correlates with the "pack / year" index and is a predictor of increased mortality in this category of patients.

2. Increased bronchial obstruction in smokers with COPD is observed with an increase in smoking history, the number of cigarettes smoked and with a decrease in body weight.

3. Reducing the pool of muscle tissue can be considered as an early predictor of more frequent exacerbations in smoking patients with COPD.

4. The systemic effects of COPD include impaired renal function, more pronounced in smokers with COPD.

\section{REFERENCES}

1. Feschenko Yu.I. KHOZL v Ukraine: problemy i puti resheniya [COPD in Ukraine: problems and solutions]. Zdorov'ya Ukrainy. 2015;9(1). (in Russian). 
2. Global Initiative for Chronic Obstructive Lung Diseases (GOLD). Global strategy for diagnosis, management, and prevention of chronic obstructive pulmonary disease. NHLBI/WHO workshop report. WHO. 2018. http://www.goldcopd.com/

3. Pertseva T.0., Gashynova K.Yu., Vikliienko Yu.I. Riven' a1-antytrypsynu (aat) u khvorykh na khronichne obstruktyvne zakhvoryuvannya lehen' (KHOZL) [Level a1-antitrypsin (AAT) in patients with chronic obstructive pulmonary disease (COPD)]. Medicni perspektivi.2011;16(2):98-104. (in Ukrainian).

4. Kovalenko 0.M., Rodionova V.V., Voronina N.0. Osoblyvosti trombotsytarnoyi lanky hemostazu u khvorykh z khronichnym obstruktyvnym zakhvoryuvannyam leheniv u spoluchenni z hipertonichnoyu khvoroboyu [Features of thrombocyte linkage of hemostasis in patients with chronic obstructive pulmonary disease in combination with hypertension]. Medicni perspektivi. 2017;3:28-33. (in Ukainian).

5. Ostrovskyi M.M., Gerych P.R. Pytannya polimorbidnosti ta komorbidnosti u patsiyentiv z KHOZL [The question of polymorbidity and comorbidity in patients with COPD]. Ukrainskiy pul'monologichniy zhurnal. 2011;4:19-24. (in Ukrainian).

6. Cao C., Wang R., Wang J., Bunjhoo H. et al. Body mass index and mortality in chronic obstructive pulmonary disease: a meta-analysis. PLoSOne. 2012;7(8):e43892. doi: 10.1371/journal.pone.0043892. Epub 2012 Aug 24. PMID: 22937118; PMCID: PMC3427325.

7. Cereda E., Pedrolli C., Zagami A., Vanotti A. et al. Body mass index and mortality in institutionalized elderly. J Am Med Dir Assoc. 2011;12(3):174-8. doi: 10.1016/j.jamda.2010.11.013. Epub 2011 Jan 11. PMID: 21333917.

8. Sarcopenia: European consensus on definition and diagnosis. Report of the European Working Group on Sarcopenia in Older People. Age Ageing. 2010;39 (4):412-423.

9. Elliott J.E., Greising S.M., Mantilla C.B., Sieck G.C. Functional impact of sarcopenia in respiratory muscles. Respir Physiol Neurobiol. 2016;226:137-146. doi:10.1016/j.resp.2015.10.001

10. Steier J., Kaul S., Seymour J. et al. The value of multiple tests of respiratory muscle strength. Thorax 2007;62(11):975-980. doi: 10.1136/thx.2006.072884.

11. Plekhova N.G., Nevzorova V.A., Rodionova L.V., Repina N.I. et al. Otsinka mozhlyvostey aterohennosti lipoproteyinovoho spektru krovi [Evaluation capabilities aterogenicity of the lipoprotein spectrum of blood]. Modern problems science and education. 2016;4. (in Ukrainian).

12. Nurgazieva D.S. Khronicheskaya bolezn' pochek u patsiyentov $s$ khronicheskoy obstruktivnoy bolezn'yu legkikh [Chronic kidney disease in patients with chronic obstructive pulmonary disease]. Bulleten' meditisnskikh Internet-konferentsiy 2016; 6(5):518. (in Russian).

13. Full Body Sensor Body Composition Monitor and Scale Model HBF-5102008. Omron instruction manual. Omron Healthcare, Inc. 1665706-3B, 2004:35.

14. Mineev V.N., Vasiljeva T.S., Deev D.M. Sushchestvuyet li risk razvitiya khronicheskoy bolezni pochek u patsiyentov s bronkhial'noy astmoy? [Is there any risk of developing chronic kidney disease in patients with bronchial asthma?] Nephrology.2017;21(4):40-47. https://doi. org/10.24884/1561-6274-2017-21-4-40-47.(in Russian.)
15. Schaap L.A., van Schoor N.M., Lips P., Visser M. Associations of sarcopenia definitions, and their components, with the incidence of recurrent falling and fractures: the longitudinal aging study Amsterdam. The Journals of Gerontology. Series A: Biological Sciences and Medical Sciences. 2018;73(9):1199-204.

16. Furutate R., Ishii T., Wakabayashi R. et al. Excessive visceral fat accumulation in advanced chronic obstructive pulmonary disease. Int J Chron Obstruct Pulmon Dis. 2011;6:423-430. doi:10.2147/COPD.S22885

17. Examination Committee of Criteria for'Obesity Disease' in Japan, Japan Society for the Study of Obesity. New criteria for 'obesity disease' in Japan. Circ. J. 2002;66(1): 987-992.

18. Rodionova V.V., Boyko 0.0., Turenko 0.A., Denisenko 0.0. Predyktory rozvytku ta prohresuvannya khronichnoyi sertsevoyi nedostatnosti u predializnykh khvorykh na khronichnu khvorobu nyrok [Predictors of chronic heart failure development and progression in pre-dialysis patients with chronic kidney disease].Kidneys.2019; 8 (1): 29-33. (in Ukrainian).

19. Agusth A.G., Noguera A., Sauleda J. et al. Systemic effects of chronic obstructive pulmonary disease. Eur. Respir. J. 2003;21(2): 347-360.

20. Rodriguez-Migueles P., Seigler N., Bass L., Dillard T.A. Assessments of endothelial function and arterial stiffness are reproducible in patients with COPD. Int. J. Chron. Obstruct. Pulmon. Dis. 2015;10:1977-1986. doi: 10.2147/COPD.S92775.

\section{ORCID and contributionship:}

Olha O. Boiko: 0000-0003-0506-0486 B,C,D

Viktoriia V. Rodionova: 0000-0002-0221-5625 A,E,F

\section{Conflict of interest:}

The Authors declare no conflict of interest.

\section{CORRESPONDING AUTHOR} Viktoriia V. Rodionova

Dnipropetrovsk Medical Academy

of the Ministry of health of Ukraine

9 V. Vernadskogo st., 49044 Dnipro, Ukraine

tel: +380962643230

e-mail: 0lhashev93@gmail.com

Received: 05.03 .2020

Accepted: 12.10 .2020

A - Work concept and design, B - Data collection and analysis, C - Responsibility for statistical analysis,

D-Writing the article, $\mathbf{E}$-Critical review, $\mathbf{F}$ - Final approval of the article 